\title{
High Temperature and Corrosion Properties of A Newly Developed Fe-Al-O Based OPH Alloy
}

\author{
Omid Khalaj ${ }^{1, *(\mathbb{C}}$, Ehsan Saebnoori ${ }^{2} \mathbb{C}$, Hana Jirková $^{1} \mathbb{D}$, Ondřej Chocholatý $^{2}$ and Jiři Svoboda $^{3}$ \\ 1 Regional Technological Institute, University of West Bohemia, Univerzitní 8, 30100 Pilsen, Czech Republic; \\ hstankov@rti.zcu.cz \\ 2 Department of Materials and Metallurgy, University of West Bohemia, Univerzitní 8, 30100 Pilsen, \\ Czech Republic; ehsan.saebnoori@gmail.com (E.S.); chochola@kmm.zcu.cz (O.C.) \\ 3 Institute of Physics of Materials, Academy of Sciences of the Czech Republic, Žižkova 22, 61662 Brno, \\ Czech Republic; svobj@ipm.cz \\ * Correspondence: khalaj@rti.zcu.cz; Tel.: +420-377638783
}

Received: 26 November 2019; Accepted: 19 January 2020; Published: 22 January 2020

check for updates

\begin{abstract}
Fe-Al-O-based materials are currently undergoing a great deal of development because of their many special properties. However, lack of strength at high temperatures, limited ductility at ambient temperatures and corrosion resistance have hindered a wider application of these materials. Recently, a new Fe-Al-based oxide precipitation hardened (OPH) steel was developed by the authors to improve the mechanical properties and oxidation resistance. The new OPH alloys are produced by dissolving a specific amount of oxygen in the matrix during mechanical alloying followed by precipitation of fine dispersion of aluminum or yttrium oxides during hot consolidation. A series of tests was performed to evaluate the thermomechanical properties and corrosion resistance in a $3.5 \%$ $\mathrm{NaCl}$ solution. The results show improved corrosion resistance, as well as mechanical properties, while the production costs of this material are lower than for traditional materials.
\end{abstract}

Keywords: OPH; corrosion; oxidation; microstructure; Fe-Al-O

\section{Introduction}

In a future environmental, ecofriendly energy industry, it will be necessary to develop new structural materials with excellent properties, including corrosion resistance and relevant high temperature strength [1-3]. Two classical groups of these metallic materials are nickel-based superalloys and oxide dispersion strengthened (ODS) ferritic steels. The single-crystal superalloys are significant because of excellent creep properties due to their microstructure, which consists of ordered cube-shaped $\gamma^{\prime}$-precipitates, separated by thin channels of the disordered $\gamma$ matrix. The instability of the $\gamma^{\prime}$-precipitates due to directional coalescence and/or coarsening above $900{ }^{\circ} \mathrm{C}$ and enormous costs seem to be the biggest disadvantages of single-crystal super alloys. On the other hand, ODS alloys consist of a matrix strengthened by a rather fine dispersion of stable oxides (usually $\mathrm{Y}_{2} \mathrm{O}_{3}$ ) with a typical size of $5-30 \mathrm{~nm}$ and with a volume fraction of about $0.5 \%$. They are made from nanocomposite powder produced by mechanical alloying (MA) of the matrix and yttrium powders, which is then hot consolidated [4-9]. ODS steels have been developed as one of the best compatible materials for high temperature applications, especially in fusion power plants. Compared with conventional ferritic/martensitic steels, ODS steels have better mechanical properties (tensile and creep strength) and oxidation resistance, thanks to the high number density of nanosized oxide particles with good thermal stability [9-12]. Such processing could be improved using a controlled thermomechanical treatment, combined with lowering the content of elements such as $\mathrm{O}, \mathrm{N}$ and $\mathrm{C}$ introduced during 
mechanical alloying $[13,14]$. ODS alloy components are also used in heat exchangers, turbines and even marine environments, so the corrosion behavior in a saline solution is an important factor.

Although the corrosion behavior of ODS alloys has been well studied in molten fluoride salts [14], liquid lead and lead-bismuth eutectic (LBE) [15], and supercritical pressurized water (SCPW) [16], the general corrosion behavior of this group of materials at room temperature has not been fully evaluated. Terada et al. reported that the corrosion resistance of Eurofer 97 steel even decreased with the percentage of oxides dispersion. Based on the various experiences of the authors $[4,17-19]$ and following the recent findings about the new generations of ODS steels, the authors have developed a new, low-cost, oxide precipitation hardened (OPH) Fe-xAl-14Cr-3 $3 \mathrm{Y}_{2} \mathrm{O}_{3}-3 \mathrm{Mo}$ steel. The matrix with various $\mathrm{wt} \%$ of $\mathrm{Al}$ is solely ferritic, without a phase transformation, up to a temperature of $1500{ }^{\circ} \mathrm{C}$, which is comparable to the mechanical properties of existing $\mathrm{Fe}-\mathrm{Cr}-\mathrm{Y}_{2} \mathrm{O}_{3}$-based ODS steels.

Recent studies show that the corrosion resistance is highly affected by $\mathrm{Al}$ content, so the optimum percentage of $\mathrm{Al}$ content is also studied considering the corrosion resistance in $3.5 \% \mathrm{NaCl}$ solution. It is reported that additions of small amounts of alloying elements to the steel $(<5 \%)$ do not increase the corrosion resistance (the condition for high temperature oxidation can be different) [20]. In contrast, low alloy steels and carbon steels are often less resistant to wet corrosion than pure iron, while elements such as carbon, manganese, aluminum, copper and silicon usually decrease the aqueous corrosion resistance of the steel [21]. On the other hand, chromium can improve the corrosion resistance of steels at high concentrations. Though, to implement this effect, the steel should contain more than $13 \%$ of chromium, while additional chromium often makes the steel even more corrosion resistant, but in ODS steels the $\mathrm{Cr}$ content should be balanced between the merit of corrosion resistance and the demerit of aging embrittlement at high temperature [21]. Therefore, in order to maintain the optimum value, the $\mathrm{Cr}$ content in ODS steels should usually be controlled to less than $16 \mathrm{wt} . \%$, and that is why we keep it at $16 \mathrm{wt}$. \% within all the variants compared in this paper.

This paper concentrates on the mechanical properties of the new OPH steel with various percentages of $\mathrm{Al}$ content, its microstructure and corrosion resistance.

\section{Experimental Procedure}

\subsection{Material Preparation}

The new Fe-Al-based OPH steel is prepared from metal powders by means of powder metallurgy [22] (Figure 1). In the first step, powders of $\mathrm{Fe}, \mathrm{Al}$ and other components (Table 1) are mechanically alloyed in a vacuum in a low energy ball mill developed by the authors. The mill is capable of sealing, evacuation or filling by a gas. The mill contains two separate steel containers (each 24 1), which are filled with 200 (100 in each) steel balls with a diameter of $40 \mathrm{~mm}$. The mill allows adjustment of the rotation frequency between $20 \mathrm{~min}^{-1}$ to $90 \mathrm{~min}^{-1}$. In the present study, a constant frequency of $75 \mathrm{~min}^{-1}$ with milling time of $250 \mathrm{~h}$ is used. The mechanical alloying (MA) increases the density of defects in the matrix of the powder and oxygen dissolves in the matrix drastically by being trapped in the defects. The solubility of interstitial oxygen in the heavily deformed matrix seems to be enormous [23]. In the second step, the MA powder is transferred to a low-alloy steel rolling container with a diameter of $20 \mathrm{~mm}$ with no contact to the air, evacuated and sealed by welding. Then a hot rolling mill is used to process the prepared materials with three steps of hot rolling. In the first step the container is heated to a temperature of $900{ }^{\circ} \mathrm{C}$ and rolled to a thickness of $7.5 \mathrm{~mm}$, and the procedure is repeated for rolling to a thickness of $5 \mathrm{~mm}$ and $3.2 \mathrm{~mm}$ in the next two steps. All the steps have a rolling speed of $0.2 \mathrm{~m} / \mathrm{s}$. An approximately $2.5 \mathrm{~mm}$ thick OPH sheet covered on both sides by $0.3 \mathrm{~mm}$ thick scale from the rolling container is produced in this way. 


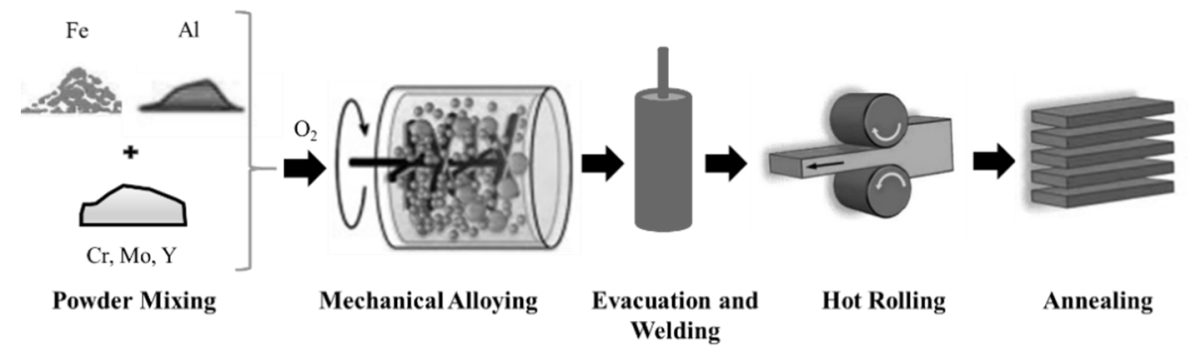

Figure 1. Material preparation process.

After the hot rolling the material is separated from the container and annealed at $1200^{\circ} \mathrm{C}$ for $20 \mathrm{~h}$, the samples for testing are cut using a water jet and ground. In this study six variants of $\mathrm{OPH}$ differing in vol. \% of $\mathrm{Al}(6 \%$ to $0.5 \%)$ are chosen as shown in Table 1 .

Table 1. Material Parameters.

\begin{tabular}{ccccc}
\hline Material No. & Milling Time (h) & Rolling Temp. $\left({ }^{\circ} \mathbf{C}\right)$ & Annealing & Chemical Composition (wt. \%) \\
\hline OP1 & 250 & 900 & $1200{ }^{\circ} \mathrm{C}, 20 \mathrm{~h}$ & $\mathrm{Fe}-6 \mathrm{Al}-14 \mathrm{Cr}-3 \mathrm{Y}_{2} \mathrm{O}_{3}-3 \mathrm{Mo}$ \\
OP2 & 250 & 900 & $1200{ }^{\circ} \mathrm{C}, 20 \mathrm{~h}$ & $\mathrm{Fe}-3.5 \mathrm{Al}-14 \mathrm{Cr}-3 \mathrm{Y}_{2} \mathrm{O}_{3}-3 \mathrm{Mo}$ \\
OP3 & 250 & 900 & $1200{ }^{\circ} \mathrm{C}, 20 \mathrm{~h}$ & $\mathrm{Fe}-2.5 \mathrm{Al}-14 \mathrm{Cr}-3 \mathrm{Y}_{2} \mathrm{O}_{3}-3 \mathrm{Mo}$ \\
OP4 & 250 & 900 & $1200{ }^{\circ} \mathrm{C}, 20 \mathrm{~h}$ & $\mathrm{Fe}-1.5 \mathrm{Al}-14 \mathrm{Cr}-3 \mathrm{Y}_{2} \mathrm{O}_{3}-3 \mathrm{Mo}$ \\
OP5 & 250 & 900 & $1200{ }^{\circ} \mathrm{C}, 20 \mathrm{~h}$ & $\mathrm{Fe}-1 \mathrm{Al}-14 \mathrm{Cr}-3 \mathrm{Y}_{2} \mathrm{O}_{3}-3 \mathrm{Mo}$ \\
OP6 & 250 & 900 & $1200{ }^{\circ} \mathrm{C}, 20 \mathrm{~h}$ & Fe-0.5Al-14Cr-3 $\mathrm{Y}_{2} \mathrm{O}_{3}-3 \mathrm{Mo}$ \\
\hline
\end{tabular}

\subsection{Specimen Preparation}

In order to optimize the sample preparation process and investigate the corrosion properties of $\mathrm{OPH}$ steels, square samples $(2 \mathrm{~cm} \times 2 \mathrm{~cm})$ are prepared to fit in the advanced corrosion cell. Moreover, standard micro-tensile samples are cut to cover the mechanical and microstructural tests for all variants of the OPH alloy. A waterjet cutting system is used to cut all the forms of the samples. The samples are cut in a longitudinal direction (parallel to the rolling direction), and the thickness of the specimens is approximately $2 \mathrm{~mm}$ after grinding.

\subsection{Testing Equipment and Procedure}

A servo-hydraulic MTS thermomechanical simulator (MTS, Minnesota, USA) and a UHL/VMHT hardness tester (Walter Uhl, Asslar, Germany) are used to carry out the mechanical tests. The purpose-built convertors (UWB, Pilsen, Czech Republic) were manufactured by the authors to hold the samples on the servo-hydraulic MTS. All of the tensile tests are carried out at room temperature (RT) with a constant strain rate of $0.001 \mathrm{~s}^{-1}$ to simulate the static conditions. The hardness tests are performed with a load of $10 \mathrm{~kg}$ and loading time of $11 \mathrm{~s}$ on the head of the surface of the polished samples. The average value is calculated from three measurements. The hardness is measured on the head of the samples for the tensile test as well as near the fracture, to see if there is a significant difference between the initial state and the deformed state of the materials. However, the values are the same with a tolerance of $0.5 \%$. A scanning electron microscope (SEM), Tescan LYRA 3 (Tescan, Brno, Czech Republic), is used for the metallographic analysis of the samples. All the cross sections are prepared using standard grinding and polishing processes. The last polishing step is performed with oxide polishing suspension (OPS). To observe the very fine microstructure, a very high magnification of $50 \mathrm{k} \times$ is used.

In order to perform the corrosion resistance evaluation of each oxide dispersion strengthened (ODS) sample, square samples with $2 \mathrm{~mm}$ thickness are cut, electrically connected with a wire, mounted in epoxy resin, and then mechanically polished with 1200 grit SiC paper. Afterwards, they are cleaned with acetone in an ultrasonic bath and rinsed with deionized water before the corrosion tests. 
Electrochemical Impedance Spectroscopy (EIS) tests are carried out in a $3.5 \% \mathrm{NaCl}$ solution at 298 K. A flat corrosion cell with three electrodes is used for the electrochemical experiments with a saturated calomel electrode (SCE), a platinum electrode, and the test sample is used as a reference, counter and working electrode, respectively. A sp-150 biologic electrochemical instrument (BioLogic Science Instruments, Seyssinet-Pariset, France) is used for the electrochemical corrosion test. EIS is performed for frequencies between $10 \mathrm{mHz}$ and $100 \mathrm{kHz}$ with alternating current (AC) amplitude of $10 \mathrm{mV}$ at open circuit potential (OCP) after $60 \mathrm{~min}$ OCP monitoring. The EIS data are then fitted to the proposed equivalent circuit using EC-Lab V 10.40 software (BioLogic Science Instruments, Seyssinet-Pariset, France).

\section{Results and Discussion}

\subsection{Metallographic Analysis}

In order to check the microstructure of all six variants after rolling, scanning electron microscopy (SEM) is used to investigate the effect of aluminum content on the grain size of these OPH alloys. Figure 2 shows the microstructures of the consolidated variants after rolling. The structures obtained are very fine grains without any signs of grain elongation due to rolling. The grains are stabilized by aluminum and Y-based nanoprecipitates [24]. The precipitates are formed during the hot rolling of the container, and/or are already during the heating of the powder to the rolling temperature. The Y-based nano-oxides are under $5 \mathrm{~nm}$, and therefore cannot be seen on the microscope scan. However, it was confirmed that they grow during annealing at $1200{ }^{\circ} \mathrm{C}$. As the nano-oxides are very stable against coarsening up to temperatures of $1000^{\circ} \mathrm{C}$, and their number density is kept very high, the Zener pinning effect is also active at these temperatures. The Zener pinning effect decreases due to the coarsening of nano-oxides at temperatures over $1200^{\circ} \mathrm{C}$, and secondary recrystallization takes place [25].

It is very difficult to measure the grain size with automatic software and therefore the evaluation is done by in-house software according to the American Society for Testing and Materials (ASTM) E112-13, "Standard Test Methods for Determining Average Grain Size". The average grain size is evaluated from five images, with 500 intersections measured for each. Figure 3 shows the average grain size versus aluminum contents for all OPH variants. It can be seen that the higher amount of aluminum resulted in coarser grains than the lower one. OP1 (6 wt. \% Al) and OP2 (3.5 wt. \% Al), with an average grain size of $115 \mathrm{~nm}$, have bigger grains compared to the other percentages of aluminum. On the other hand, all four other variants (OP3, OP4, OP5, OP6) have almost the same average grain size of $103 \mathrm{~nm}$, which is $10 \%$ less than OP1 and OP2. This trend confirms the influence of aluminum upon recrystallization.

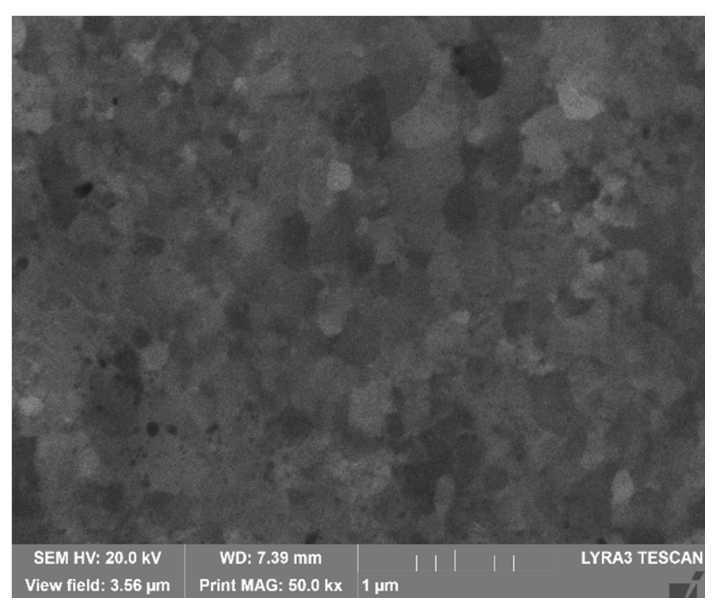

(a)

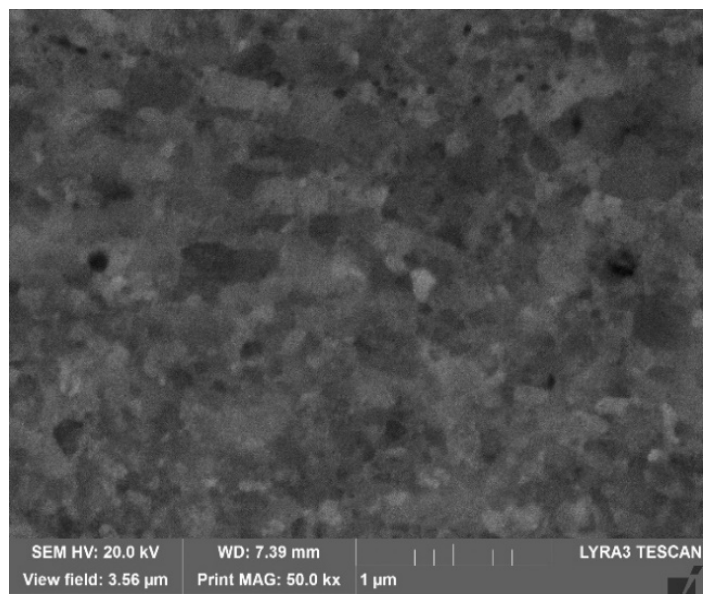

(b)

Figure 2. Cont. 


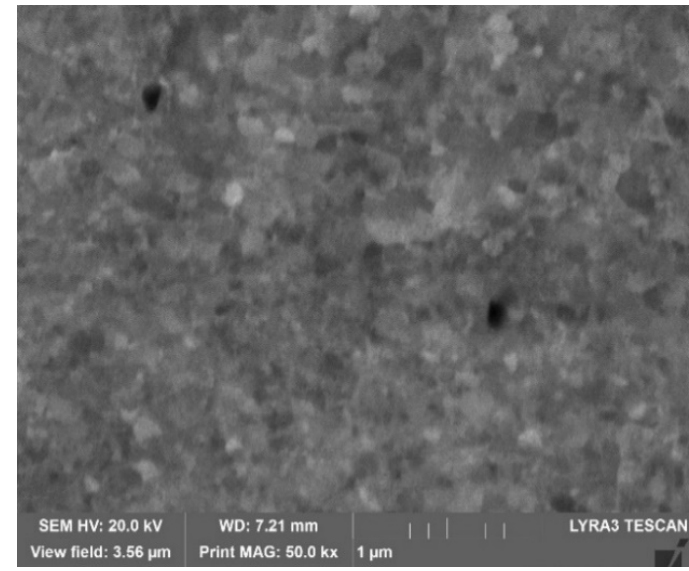

(c)

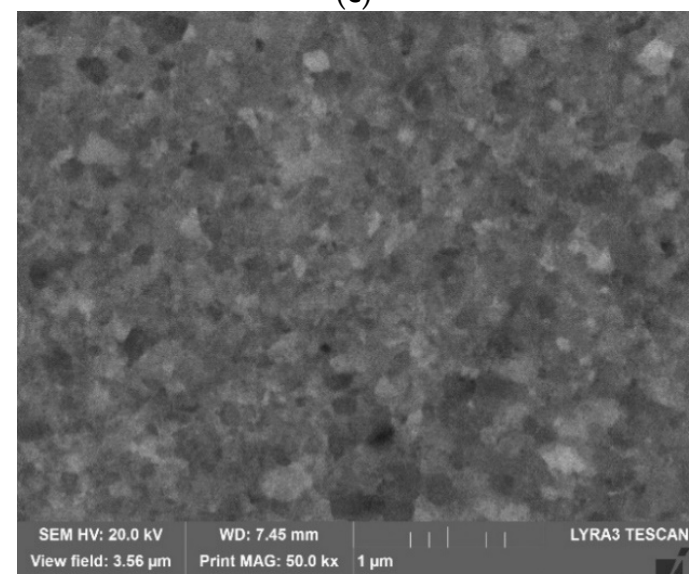

(e)

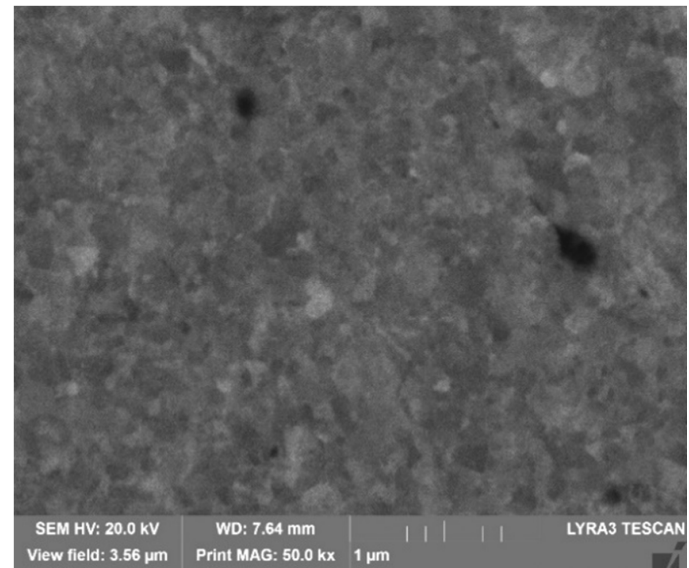

(d)

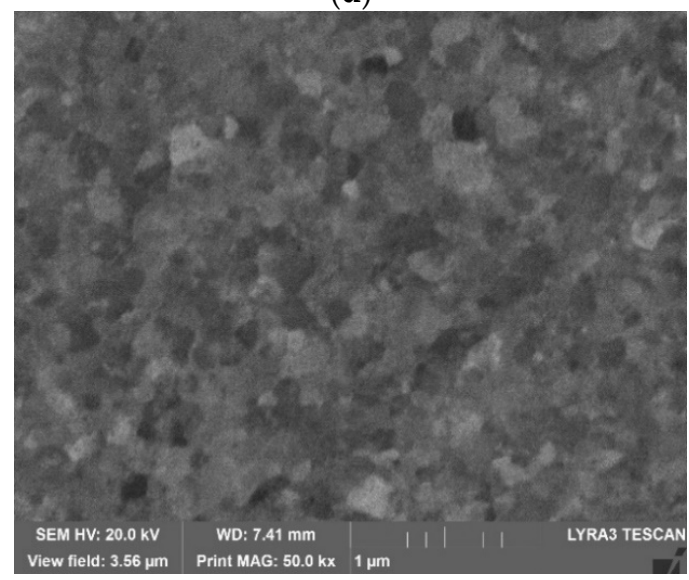

(f)

Figure 2. Microstructures of the consolidated (a) OP1, (b) OP2, (c) OP3, (d) OP4, (e) OP5 and (f) OP6.

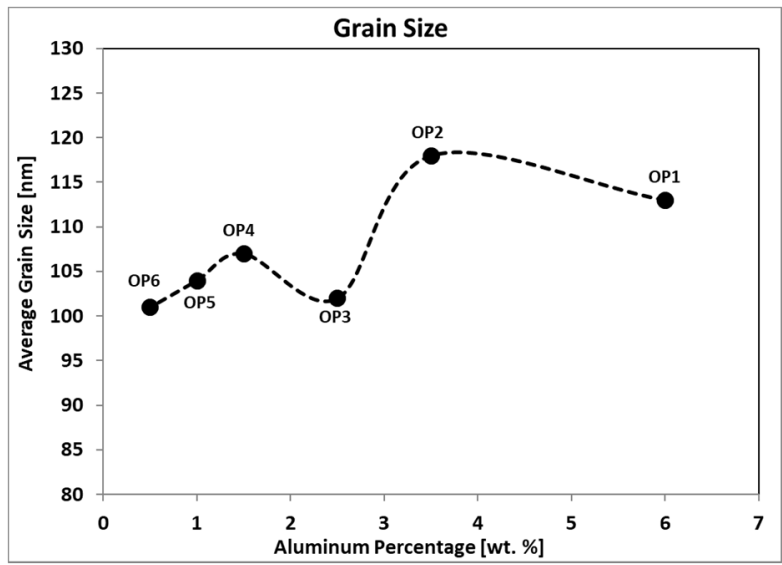

Figure 3. Average grain size of all oxide precipitation hardened $(\mathrm{OPH})$ variants.

\subsection{Mechanical Properties}

Figure 4 shows the hardness (HV10) test results for different OPH variants before annealing. The results show that the different Al contents in the OPH alloy has no significant effect on the hardness of these materials. The maximum hardness was found to be near $730 \mathrm{HV} 10$ in the range of Al between 1.5 to $3 \mathrm{wt}$. \%, while the average hardness stands near 700 HV10. OP1 (maximum Al content) and OP6 (minimum aluminum content) show the minimum hardness near 670 HV10. 


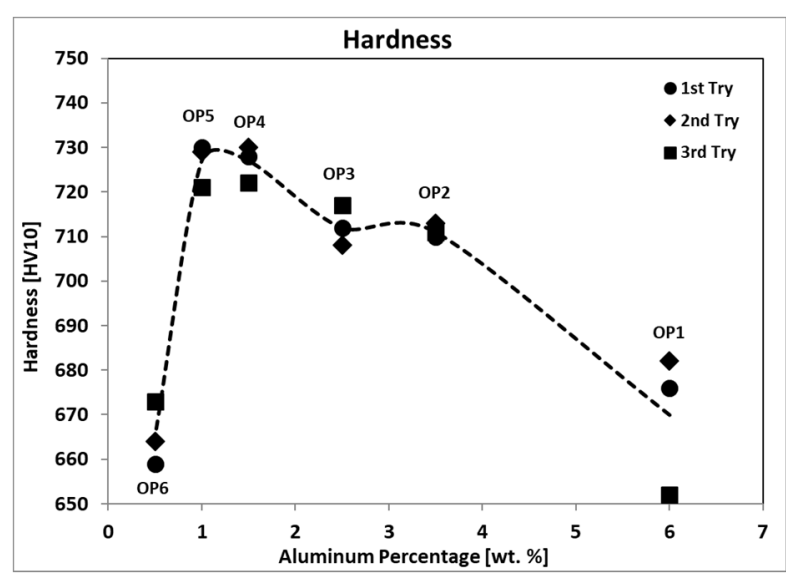

Figure 4. Hardness (HV10) at room temperature (RT).

In order to better understand the mechanical properties of all six variants of $\mathrm{OPH}$, tensile tests at RT are performed. Figure 5 shows the ultimate tensile strength (UTS) for OPH alloys with different percentages of $\mathrm{Al}$ after annealing.

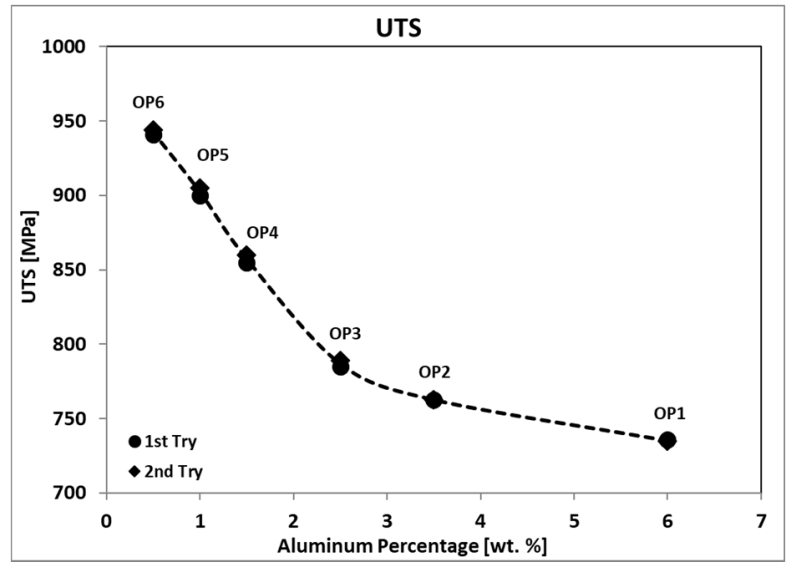

Figure 5. Ultimate tensile strength (UTS) for $\mathrm{OPH}$ with different percentage of Al.

The results show that the UTS decreases as Al content increases. Previous experiences of the authors show that the average UTS for such an OPH with similar chemical components is between 800 to $900 \mathrm{MPa}[18,26,27]$, which confirms the measured results. Such a high value of UTS is most probably caused by the rather high number density of oxides in the OPH alloy. The influence of excess oxygen on the tensile strength is also confirmed by previous research $[17,18,28]$, reporting that for a low content of $0.12 \%$ oxygen, almost the highest tensile strength is achieved, while higher excess oxygen made the tensile properties deteriorate. The deterioration can, however, be explained by the fact that the excess oxygen is not bound in stable oxides. In all cases, the solubility of oxygen in the matrix is practically zero, and all oxygen is present in the oxides of elements with the highest affinity to oxygen. That is why UTS variation is due to strengthening by oxides, and the different behavior of tensile properties correlates with the different grain and oxide particle distribution, because the hard dispersoids like oxides are bypassed by the formation of Orowan loops. Finer size and a higher number density of oxide particles lead to higher Orowan stress. In addition, uniform distribution of grains and oxide particles also affect the ductility of ODS steels. Moreover, high excess oxygen concentration may cause an inhomogeneous microstructure with a co-existence of fine and coarse oxide particles as well as grains, which could lead to a decrease of UTS. 
The aluminum content together with chromium plays a very important role in the high corrosion resistance of ODS steels [29]. Lee et al. reported that ODS steel with chromium content between $14 \%$ to $16 \%$ should contain aluminum between $3.5 \%$ to $4.5 \%$ to generate a dense and adherent alumina layer [30]. But the results from tensile testing showed that the increased content of alumina has a negative influence on the mechanical properties and the tensile strength is decreased from $950 \mathrm{MPa}$ to approximately $750 \mathrm{MPa}$ (Figure 5). This was due to the reaction of alumina with $\mathrm{Y}_{2} \mathrm{O}_{3}$, because the $\mathrm{Y}_{2} \mathrm{O}_{3}$ always reacts with alumina and residual oxygen to form coarse $\mathrm{Y}-\mathrm{Al}-\mathrm{O}$ particles (YAP, $\mathrm{YAlO}_{3}$ and $\mathrm{YAG}, \mathrm{Y}_{3} \mathrm{Al}_{5} \mathrm{O}_{12}$ ). Without $\mathrm{Al}$, the $\mathrm{Y}_{2} \mathrm{O}_{3}$ can combine with Ti and form finer and more stable $\mathrm{Y}_{2} \mathrm{Ti}_{2} \mathrm{O}_{7}$ nanoparticles [31]. To improve the mechanical properties of ODS steel, the coherent or semi-coherent interface between nanoparticles and the matrix is also important. Therefore also the $\mathrm{Y}-\mathrm{Al}-\mathrm{O}$ particles are not preferable for ODS steel [31]. The results also showed that there is almost no correlation between hardness values and tensile strength. For the hardness measurement, the interface between nanoparticles and the matrix is not so important. But, although the UTS should increase with the decreasing grain size, it seems that the UTS is predominantly determined by the amount of Al in the matrix.

Somehow, a linear correlation between hardness and UTS exists, but cannot be overestimated, since these properties are measurements of different capabilities of the material. UTS comes from tensile strength, which is the ability to resist being tensioned in one direction. The cause for the materials to fail or break when tensioned are the cracks that grow and compromise their integrity. On the other hand, hardness measures the resistance a surface has to being penetrated, which can reflect predominantly the properties from compressive tests. The entire load dispersion in the material is different and the material does not break, but is deformed. That being said, since the mechanisms of deformation and failure are not the same, one cannot directly compare these properties. If cast iron is taken as an example, its hardness is high and its tensile strength resistance is low, showing the independence between parameters. In the case of rather brittle materials the correlation can be rather weak [32,33].

\subsection{Corrosion Properties}

Electrochemical impedance spectroscopy is measured on OP1 to OP6 after annealing with different aluminum contents. Figure $6 \mathrm{a}-\mathrm{c}$ show the Nyquist and Bode plots. Each plot consists of two capacitive loops. The large capacitive loop in the high frequency region is related to the double electric layer formed at the electrode/electrolyte interface [34], and the small capacitive loop in the low frequency region is caused by the passive film formed at the electrode surface [35]. Due to the presence of impermeable defects in the oxide surface layer, the capacitive loops are combined in parallel circuit. In the case of the Nyquist curves with two semicircles, the porous film equivalent circuit is often employed.

This circuit, which is equivalent to electrochemical reactions, takes place in the metal-oxide layer interface. The first semicircle (high frequency semicircle), indicates the electrochemical behavior of the outer layer, and the second semicircle (low-frequency semicircle) indicates the reactions occurring in the oxide layer. Many oxide-covered alloys behave like this in chloride-containing solutions [36,37]. The corrosion resistance is measured in the recrystallized state (after annealing), thus the grain size after rolling is irrelevant. The results of corrosion tests indicate that the $\mathrm{Al}$ content has a detrimental influence on the corrosion resistance at RT, but its influence can significantly change for corrosion at high temperatures in the presence of oxygen, when the formation of a protective alumina film may play a decisive role.

EIS plots of the OPH alloys are fitted with equivalent circuits shown in Figure 6d, and the EIS fitting results are presented in Table 2. Rs, Rpore and Rct are the solution resistance, passive film resistance, and charge transfer resistance, respectively. The constant phase element (CPE) is employed to evaluate the double electric layer at the electrode/electrolyte interface [36]. The electrical impedance of this CPE can be calculated from Equation (1). 


$$
Z_{C P E}=\frac{1}{Q(j . \omega)^{n}}
$$

where $Q$ represents the capacitance of the double electric layer/oxide film, respectively, and $\mathrm{n}$ shows the closeness to the pure capacitance; for $n=1, \mathrm{CPE}$ can be replaced with a pure capacitor. As it is understood from Figure 6 and Table 2, the accumulative resistances of the samples are increased from OP1 to OP6 while the aluminum content is decreased. Since the aluminum content of the samples is the main difference between the variants, the graph of charge transfer resistance (Rct) versus the aluminum percentage is plotted in Figure 7 as an exponential trend. It is also reported that the aluminum has a great effect on the mechanical behavior and microstructure of steels [38], but there are few reports on the corrosion resistance of steel with a high notable amount of aluminum. Aluminum is frequently used as a deoxidizing agent in steels which forms aluminum oxide $\left(\mathrm{Al}_{2} \mathrm{O}_{3}\right)$ and takes out the oxygen from the steel to produce deoxidized steel. Aluminum can also react with nitrogen in the melt and form AlN [39]. On the other hand, due to the very negative electrochemical potential of aluminum, more aluminum in the steel produces active phases and increases the corrosion reactions which can clearly be seen in Figure 7.

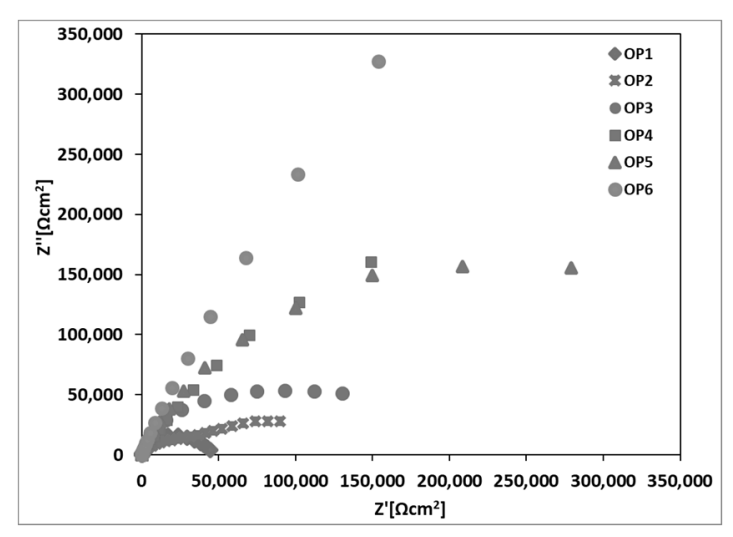

(a)

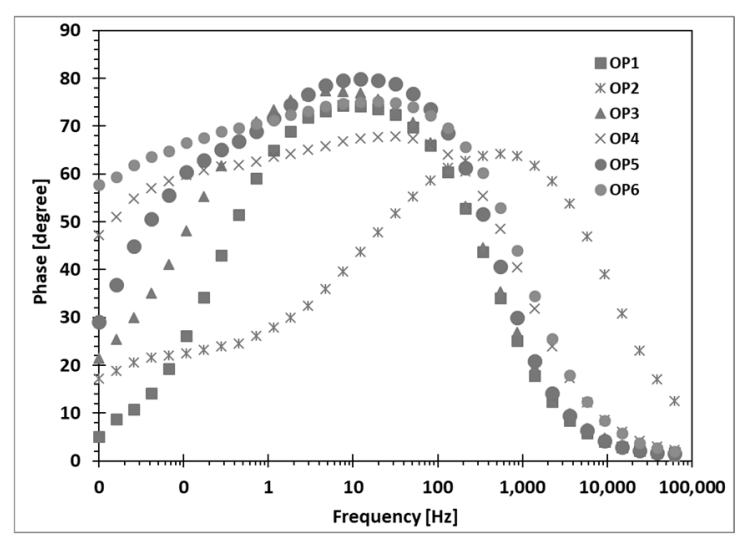

(c)

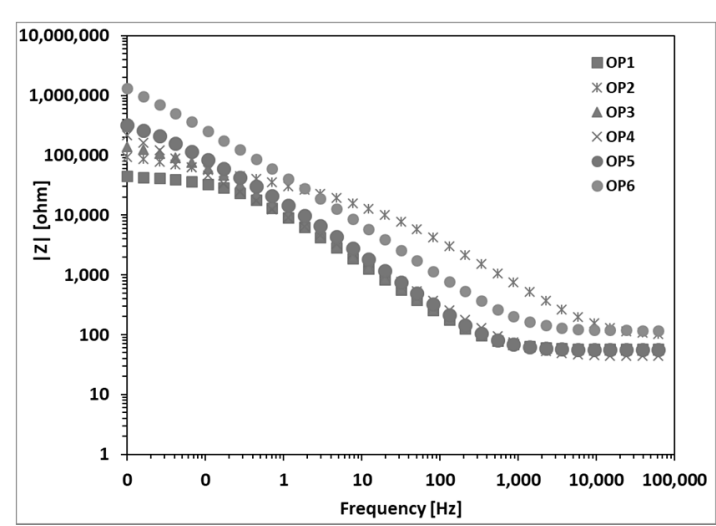

(b)

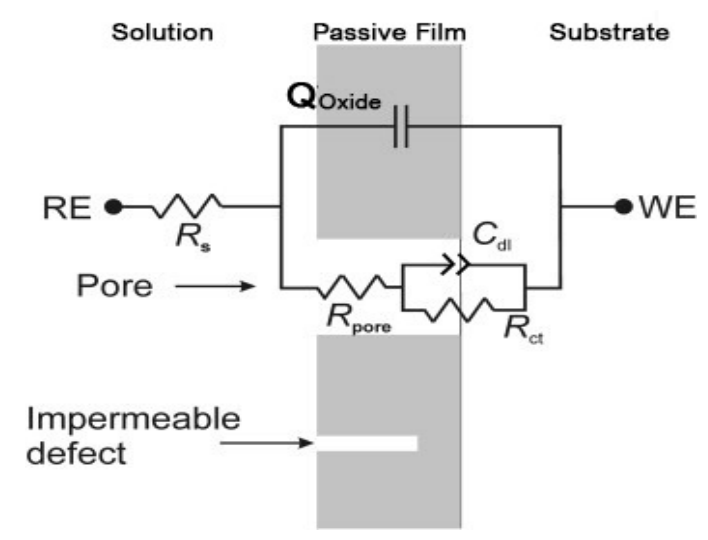

(d)

Figure 6. Electrochemical impedance spectra (EIS) of $\mathrm{OPH}$ variants in $3.5 \mathrm{wt}$. \% $\mathrm{NaCl}$ solution (a) Nyquist diagram (b) Bode phase, (c) Bode modulus and (d) equivalent circuit models for the impedance spectra. 
Table 2. Electrochemical parameters of OP samples obtained from fitting the electrochemical impedance spectra in Figure 6.

\begin{tabular}{|c|c|c|c|c|c|c|c|c|c|}
\hline ID & $\begin{array}{l}\text { Al Cont. } \\
\text { (wt. \%) }\end{array}$ & $\begin{array}{l}\text { Rs } \\
(\Omega)\end{array}$ & $\begin{array}{l}\text { Rpore } \\
(\mathrm{k} \Omega)\end{array}$ & $\begin{array}{c}\text { Qpore-T } \\
\left(\mu \mathrm{F} \cdot s^{\wedge}\left(a^{-1}\right)\right)\end{array}$ & Qpore-P & $\begin{array}{c}\text { Rct } \\
(\mathrm{k} \Omega)\end{array}$ & $\begin{array}{c}\text { Qct-T } \\
\left(\mu \mathrm{F} \cdot s^{\wedge}\left(a^{-1}\right)\right)\end{array}$ & Qct-P & $\begin{array}{c}\text { Chi } \\
\text { Squared }\end{array}$ \\
\hline OP1 & 6.2 & 96 & 5 & 9.08 & 0.70 & 13 & 732.70 & 0.80 & $1.60 \times 10^{-4}$ \\
\hline OP2 & 3.6 & 93 & 5 & 1.15 & 0.82 & 366 & 17.89 & 0.68 & $1.45 \times 10^{-3}$ \\
\hline OP3 & 2.4 & 94 & 50 & 1.14 & 0.88 & 6,59 & 1.06 & 0.88 & $9.13 \times 10^{-4}$ \\
\hline OP4 & 1.5 & 90 & 72 & 3.79 & 0.87 & 17,51 & 1.90 & 0.74 & $1.18 \times 10^{-4}$ \\
\hline OP5 & 0.9 & 55 & 87 & 16.43 & 0.88 & 37,63 & 3.58 & 0.61 & $1.86 \times 10^{-3}$ \\
\hline OP6 & 0.3 & 88 & 17 & 0.39 & 0.88 & 91,50 & 1.47 & 0.64 & $4.18 \times 10^{-4}$ \\
\hline
\end{tabular}

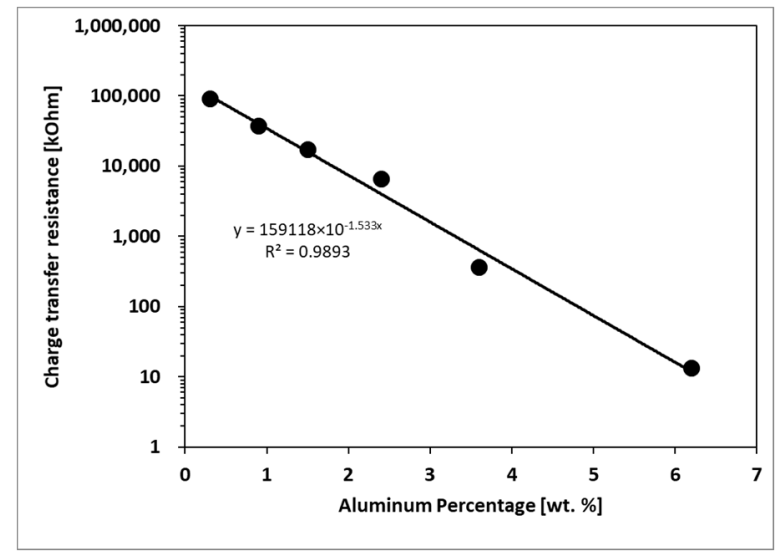

Figure 7. The charge transfer resistance (Rct) extracted from fitting the EIS curves vs. Al content.

\section{Conclusions}

The mechanical properties, corrosion resistance, hardness and microstructure of six different variants of a newly developed Fe-Al-O-based OPH alloy were investigated using a number of different tests. The results show that the aluminum content has a significant role on the mechanical and corrosion properties of these materials while it has less effect on the hardness value. Increasing the aluminum content has a negative influence on the tensile strength which decreased from $950 \mathrm{MPa}$ to approximately $750 \mathrm{MPa}$. This is due to the reaction of aluminum with $\mathrm{Y}_{2} \mathrm{O}_{3}$ as the $\mathrm{Y}_{2} \mathrm{O}_{3}$ always reacts with aluminum and residual oxygen to form coarse $\mathrm{Y}-\mathrm{Al}-\mathrm{O}$ particles (YAP, $\mathrm{YAlO}_{3}$ and YAG, $\mathrm{Y}_{3} \mathrm{Al}_{5} \mathrm{O}_{12}$ ). On the other hand, the hardness value after rolling was in the range of 650 to $750 \mathrm{HV} 10$ for all tested ODS steels. The results showed no appropriate correlation between hardness values and tensile strength depending on the aluminum content. Besides, the UTS is predominantly determined by the amount of $\mathrm{Al}$ in the matrix. A higher amount of aluminum resulted in coarser grains up to $115 \mathrm{~nm}$ after hot rolling.

The results of corrosion tests indicate that the $\mathrm{Al}$ content has a detrimental influence on the corrosion resistance at RT, but its influence can significantly change at elevated temperatures in the presence of oxygen, when the formation of a protective alumina film may play a decisive role. The corrosion resistance is increased by increasing the amount of aluminum.

Author Contributions: Conceptualization, J.S., H.J. and O.K.; methodology, O.K., H.J., J.S. and E.S.; software, O.K. and E.S.; validation, O.K., H.J., J.S., E.S. and O.C.; formal analysis, O.K. and E.S.; investigation, O.K. and E.S.; resources, O.K., J.S., H.J. and E.S.; data curation, O.K., J.S., H.J. and E.S.; writing—original draft preparation, O.K. and E.S.; writing-review and editing, O.K., J.S., H.J. and E.S.; visualization, O.K. and E.S.; supervision, J.S.; project administration, H.J.; funding acquisition, J.S. and H.J. All authors have read and agreed to the published version of the manuscript.

Funding: This research was funded by “Grantová Agentura České Republiky (GAČR), The Czech Science Foundation, grant number 17-01641S" and "The APC was funded by 1500 CHF".

Conflicts of Interest: The authors declare no conflict of interest. 


\section{References}

1. Murty, K.L.; Charit, I. Structural materials for Gen-IV nuclear reactors: Challenges and opportunities. J. Nucl. Mater. 2008, 383, 189-195. (In English) [CrossRef]

2. Odette, G.R.; Alinger, M.J.; Wirth, B.D. Recent developments in irradiation-resistant steels. Annu. Rev. Mater. Res. 2008, 38, 471-503. (In English) [CrossRef]

3. Yvon, P.; Carré, F. Structural materials challenges for advanced reactor systems. J. Nucl. Mater. 2009, 385, 217-222. [CrossRef]

4. Masek, B.; Khalaj, O.; Novy, Z.; Kubina, T.; Jirkova, H.; Svoboda, J.; Stadler, C. Behaviour of new ODS alloys under single and multiple deformation. Mater. Tehnol. 2016, 50, 891-898. [CrossRef]

5. Pollock, T.M.; Argon, A.S. Directional coarsening in nickel-base single-crystals with high-volume fractions of coherent precipitates. Acta Metallurgica et Materialia 1994, 42, 1859-1874. (In English) [CrossRef]

6. Svoboda, J.; Lukáš, P. Model of creep in <001>-oriented superalloy single crystals. Acta Mater. 1998, 46, 3421-3431.

7. Svoboda, J.; Lukáš, P. Creep deformation modelling of superalloy single crystals. Acta Mater. 2000, 48, 2519-2528. (In English) [CrossRef]

8. Khalaj, O.; Masek, B.; Jirkova,H.; Ronesova, A.; Svoboda, J. Investigation on new creep- and oxidation-resistant materials. Mater. Tehnol. 2015, 49, 645-651. (In English) [CrossRef]

9. Certain, A.G.; Field, K.G.; Allen, T.R.; Miller, M.K.; Bentley, J.; Busby, J.T. Response of nanoclusters in a $9 \mathrm{Cr}$ ODS steel to $1 \mathrm{dpa}, 525$ degrees C proton irradiation. J. Nucl. Mater. 2010, 407, 2-9. (In English) [CrossRef]

10. Cho, H.S.; Kimura, A. Corrosion resistance of high-Cr oxide dispersion strengthened ferritic steels in super-critical pressurized water. J. Nucl. Mater. 2007, 367, 1180-1184. (In English) [CrossRef]

11. Schneibel, J.H.; Liu, C.T.; Hoelzer, D.T.; Mills, M.J.; Sarosi, P.; Hayashi, T.; Wendt, U.; Heyse, H. Development of porosity in an oxide dispersion-strengthened ferritic alloy containing nanoscale oxide particles. Scr. Mater. 2007, 57, 1040-1043. (In English) [CrossRef]

12. Steckmeyer, A.; Praud, M.; Fournier, B.; Malaplate, J.; Garnier, J.; Béchade, J.L.; Tournié, I.; Tancray, A.; Bougault, A.; Bonnaillie, P. Tensile properties and deformation mechanisms of a 14Cr ODS ferritic steel. J. Nucl. Materials 2010, 405, 95-100. (In English) [CrossRef]

13. Li, W.; Xu, H.; Sha, X.; Meng, J.; Wang, Z. Microstructure and mechanical properties of 14Cr-ODS steels with Zr addition. High. Temp. Mater. Process. 2019, 38, 404-410. (In English) [CrossRef]

14. Xu, H.; Lu, Z.; Jia, C.; Gao, H.; Liu, C. Microstructure and mechanical property of 12Cr oxide dispersion strengthened steel. High. Temp. Mater. Process. 2016, 35, 321-325. (In English) [CrossRef]

15. Kimura, A.; Kasada, R.; Iwata, N.; Kishimoto, H.; Zhang, C.H.; Isselin, J.; Dou, P.; Lee, J.H.; Muthukumar, N.; Okuda, T.; et al. Development of Al added high-Cr ODS steels for fuel cladding of next generation nuclear systems. J. Nucl. Mater. 2011, 417, 176-179. (In English) [CrossRef]

16. Ohtsuka, S.; Ukai, S.; Fujiwara, M.; Kaito, T.; Narita, T. Nano-structure control in ODS martensitic steels by means of selecting titanium and oxygen contents. J. Phys. Chem. Solids 2005, 66, 571-575. (In English) [CrossRef]

17. Khalaj, O.; Mašek, B.; Jirková, H.; Svoboda, J. Experimental Study on Thermomechanical properties of new-generation ODS alloys. J. Chem. Mol. Nucl. Mater. Metall. Eng. 2017, 11, 456-459.

18. Khalaj, O.; Jirková, H.; Janda, T.; Kučerová, L.; Studený, T.; Svoboda, J. Improving the high temperature properties of a new generation of Fe-Al-O oxide precipitation hardened steels. Mater. Tehnol. 2019, 53, 495-504. [CrossRef]

19. Khalaj, O.; Masek, B.; Jirkova, H.; Svoboda, J.; Bublikova, D. Influence of thermomechanical treatment on the grain-growth behaviour of new Fe-Al based alloys with fine $\mathrm{Al}_{2} \mathrm{O}_{3}$ precipitates. Mater. Technol. 2017, 51, 759-768.

20. Townsend, H.E. Effects of alloying elements on the corrosion of steel in industrial atmospheres. Corrosion 2001, 57, 497-501. (In English) [CrossRef]

21. Revie, R.W. Uhlig's Corrosion Handbook; John Wiley \& Sons: Hoboken, NJ, USA, 2011.

22. Kumar, D.; Prakash, U.; Dabhade, V.V.; Laha, K.; Sakthivel, T. High yttria ferritic ODS steels through powder forging. J. Nucl. Mater. 2017, 488, 75-82. (In English) [CrossRef]

23. Svoboda, J.; Ecker, W.; Razumovskiy, V.I.; Zickler, G.A.; Fischer, F.D. Kinetics of interaction of impurity interstitials with dislocations revisited. Prog. Mater. Sci. 2019, 101, 172-206. (In English) [CrossRef] 
24. Bártková, D.; Šmíd, M.; Mašek, B.; Svoboda, J.; Šiška, F. Kinetic study of static recrystallization in an Fe-Al-O ultra-fine-grained nanocomposite. Philos. Mag. Lett. 2017, 97, 379-385. [CrossRef]

25. Svoboda, J.; Hornik, V.; Stratil, L.; Hadraba, H.; Masek, B.; Khalaj, O.; Jirkova, H. Microstructure evolution in ODS alloys with a high-volume fraction of nano oxides. Metals 2018, 8, 1079. (In English) [CrossRef]

26. Khalaj, O.; Jirková, H.; Opatová, K.; Svoboda, J. Microstructural and Hardness Evolution of New Developed OPH Steels. In Solid State Phenomena; Trans Tech Publications Ltd.: Baech, Switzerland, 2019; Volume 294, pp. 92-97.

27. Khalaj, O.; Jirkova, H.; Masek, B.; Hassasroudsari, P.; Studecky, T.; Svoboda, J. Using thermomechanical treatments to improve the grain growth of new-generation Ods alloys. Mater. Tehnol. 2018, 52, 475-482. [CrossRef]

28. Zhao, H.; Liu, T.; Bai, Z.; Wang, L.; Gao, W.; Zhang, L. Corrosion behavior of 14Cr ODS steel in supercritical water: The influence of substituting Y2O3 with Y2Ti2O7 nanoparticles. Corros. Sci. 2020, 163, 108272. [CrossRef]

29. Lee, J.H.; Kasada, R.; Kimura, A.; Okuda, T.; Inoue, M.; Ukai, S.; Ohnuki, S.; Fujisawa, T.; Abe, F. Influence of alloy composition and temperature on corrosion behavior of ODS ferritic steels. J. Nucl. Mater. 2011, 417, 1225-1228. (In English) [CrossRef]

30. Alinger, M.J.; Odette, G.R.; Hoelzer, D.T. On the role of alloy composition and processing parameters in nanocluster formation and dispersion strengthening in nanostuctured ferritic alloys. Acta Mater. 2009, 57, 392-406. (In English) [CrossRef]

31. Liu, T.; Shen, H.L.; Wang, C.X.; Chou, W.S. Structure evolution of Y2O3 nanoparticle/Fe composite during mechanical milling and annealing. Prog. in Nat. Sci.-Mater. Int. 2013, 23, 434-439. (In English) [CrossRef]

32. Hong, S.; Kim, S.H.; Kim, T.K.; Jang, C. Effect of thermal ageing on mechanical properties of a high-strength ODS alloy. J. Mech. Sci. Technol. 2016, 30, 4427-4431. (In English) [CrossRef]

33. Sanctis, M.; Fava, A.; Lovicu, G.; Montanari, R.; Richetta, M.; Testani, C.; Varone, A. Mechanical characterization of a nano-ODS steel prepared by low-energy mechanical alloying. Metals 2017, 7, 283. [CrossRef]

34. Salimi, S.; Nasr-Esfahani, M.; Umoren, S.A.; Saebnoori, E. Complexes of Imidazole with Poly (ethylene glycol) as a Corrosion Inhibitor for Carbon Steel in Sulphuric Acid. J. Mater. Eng. Perform. 2015, 24, 4696-4709. [CrossRef]

35. Saebnoori, E.; Shahrabi, T.; Sanjabi, S.; Ghaffari, M.; Barber, Z.H. Surface characteristics and electrochemical behaviour of sputter-deposited NiTi thin film. Philos. Mag. 2015, 95, 1696-1716. [CrossRef]

36. Liu, Y.; Wang, Z.Y.; Wei, Y.H. Influence of seawater on the carbon steel initial corrosion behavior. Int. J. Electrochem. Sci. 2019, 14, 1147-1162. (In English) [CrossRef]

37. Yang, D.; Huang, Y.; Peng, P.; Liu, X.; Zhang, B.B. Passivation behavior and corrosion resistance of 904L austenitic stainless steels in static seawater. Int. J. Electrochem. Sci. 2019, 14, 6133-6146. (In English) [CrossRef]

38. Alaneme, K.K.; Fajemisin, A.V.; Maledi, N.B. Development of aluminium-based composites reinforced with steel and graphite particles: Structural, mechanical and wear characterization. J. Mater. Res. Technol. 2019, 8, 670-682. [CrossRef]

39. Deng, X.; Ji, C.; Guan, S.; Wang, L.; Xu, J.; Tian, Z.; Cui, Y. Inclusion behaviour in aluminium-killed steel during continuous casting. Ironmak. Steelmak. 2019, 46, 522-528. [CrossRef]

(C) 2020 by the authors. Licensee MDPI, Basel, Switzerland. This article is an open access article distributed under the terms and conditions of the Creative Commons Attribution (CC BY) license (http://creativecommons.org/licenses/by/4.0/). 